\title{
COD reduction studies of paper mill effluent using a batch recirculation electrochemical method
}

\author{
Kannadasan, T. ${ }^{1}$, Sivakumar, V. ${ }^{2}$, Ahmed Basha, C. ${ }^{3}$, Arun V. Parwate ${ }^{4}$, Senthilkumar, K. ${ }^{5^{*}}$, \\ Kannan, K. ${ }^{6}$ \\ ${ }^{1}$ Coimbatore Tamilnadu, Department of Chemical Engineering, Coimbatore Institute of Technology, Professor and Head, \\ India \\ ${ }^{2}$ Kongu Engineering College, Department of Food Technology, Head of Department, Perundurai, Erode-638052, Tamilnadu, \\ India \\ ${ }^{3}$ Karaikudi Tamilnadu, Central Electrochemical Research Institute, India \\ ${ }^{4}$ Erode Sengunthar Engineering College, Principal, Thudupathi, Erode-638057, Tamilnadu, India \\ ${ }^{5}$ Erode Sengunthar Engineering College, Department of Chemical Engineering, Thudupathi,Erode-638057, Tamilnadu, \\ India \\ ${ }^{6}$ Kongu Engineering College, Department of Chemical Engineering, Perundurai, Erode-638052, Tamilnadu, India \\ * Corresponding Author: e-mail: uksen2003@yahoo.co.in
}

\begin{abstract}
The conventional method of treating pulp and paper mill effluent involves the biological oxidation by bacterial action of aerobic and anaerobic conditions and aerobic lagooning method, which are less efficiency of removing COD. To overcome the drawbacks of the existing treatment process, in the present work an attempt has been made to study the electro oxidative destruction of the pulp and paper mill effluent using an electrochemical method and the effect of various parameters such as concentration of supporting electrolytes, current densities, flow rates of electrolyte and reservoir volumes of the effluent were conducted. From the experimental results it is observed that the rate of reduction of COD of the effluent increased with an increase in the supporting electrolyte (sodium chloride) concentration, current density where as it decreased with increase in the reservoir volume and the flow rate of electrolyte. The residence time distributions studies have also been conducted to study the behavior of the electrochemical reactor.
\end{abstract}

Keywords: effluent treatment, residence time distributions, electrochemical reactor, Pulp and Paper mill effluent.

\section{INTRODUCTION}

The enormous growth of various industries such as chemical, metallurgical and others contribute to the financial stability of a nation. Due to the rapid industrial growth, our country has experienced excellent living standards. But it has also a major defect, namely environmental pollution. The term pollution implies the introduction of extraneous matter into the environment, either directly or indirectly which can occur in the solid, liquid, or gaseous forms. This pollution leads to several hazards of the entire eco system ${ }^{\mathbf{1}, 2}$. The pulp and paper mills are, in general, regarded as heavy pollutants of water because of a large use of chemicals. The water pollutants of pulp and paper mills included a wide variety of chemicals such as lignin and other chemicals from wood, bamboo etc, caustic soda, sodium sulphide, sodium sulphate, sodium-bi-sulphate, chlorine, fillers like talc, titanium oxide, aluminium suplhate and trace metals like chromium, lead, mercury, etc., depending upon the raw materials used and the manufacturing process adopted. The effluents are generally very alkaline and have high chemical oxygen demands. The methods which can be conveniently employed for the treatment of black liquor are primary treatment such as sedimentation, coagulation, flocculation and floatation and secondary treatment such as trickling filter, activated sludge, oxidation pond and lagoon. These are conventional treatment methods, and may not be economically viable for small and medium scale pulp and paper industries. The conventional trickling filter or activated sludge process is not only costly to install but also difficult to maintain and operate at the desired level of efficiency ${ }^{2-4}$.
A review of the previous work have been undertaken in order to achieve a systematic and proper procedure for accomplishing the aim of this investigation. During the review of the published material it was found that great emphasis had been put on treating various industrial effluents using electrochemical methods ${ }^{5-8}$. The electrochemical processes involve the direct reaction of species at electrode surface, while others involves the production of active species at the electrode and further reaction with the targeted pollutants. In electrochemical processes, hypochlorite was formed which was the strong oxidizing and bleaching agent ${ }^{9}$. The advantages of the electrochemical methods are the high efficiency of conversion, the reuse of the treated water is possible and the main reagent used is the electron which was a clean reagent and usually there is no need for adding extra chemicals which may introduce other pollutants, etc. ${ }^{10,11}$. To overcome the drawbacks of the existing treatment process, in the present work an attempt to study the treatment of paper mill effluent by using an electrochemical method and conducting the experiments in an electrochemical reactor with electrolytic recirculation ${ }^{12}$. Besides residence time distribution (RTD) studies have also been conducted to study the behavior of the electrochemical reactor and for which, impulse input of the tracer was suddenly injected. Different fluid elements take different roots to reach an exit from the entrance of the reactors. This leads to the distribution of residence time within the reactor. This is called residence time distribution (TRD). In a real reactor, neither plug-flow nor CSTER (Continuous Stirred Tank Electrochemical Reactor) conditions are vigorously satisfied and one may expect that plug 
flow and back mix flow are superimposed ${ }^{13}$. The computation of the dispersion coefficient is closely linked to RTD in an electrochemical reactor ${ }^{9}$.

\section{EXPERIMENTAL SETUP AND PROCEDURE}

The electrolytic reactor cell composed of a lead dioxide coated on expanded titanium mesh as anode and a stainless steel sheet as cathode under galvonostatic process. The dimensions of the electrodes were $0.07 \mathrm{~m} \times 0.07 \mathrm{~m}$. The schematic of the experimental setup is shown in Figure 1. The effluent was mixed with the known amount of the supporting electrolyte (sodium chloride) and pumped from the reservoir using a pump to the reactor cell which is in rectangular shape. The effluent of the known volume, for example 1 litre, was taken in the reservoir. The effluent treated in the reactor cell was recirculated to the reservoir. The effluent was treated under the galvonostatic process at 3 different reservoir volumes such as 1, 1.5 and 2 litres. For each reservoir volume the experiment was repeated for five different flow rates of the effluent to the reactor cell such as $20,40,60,80$ and $100 \mathrm{LPH}$. The flow rate was measured by using the calibrated rotameter. For all the conditions, the experiment was run for $8 \mathrm{hrs}$. A multimeter was connected parallel with the cell to measure the cell voltage between the electrodes periodically and the samples during recirculation were collected for each one hour, kept under acidic conditions and were subjected to COD analysis. Chemical oxygen demand (COD) is defined as the amount of oxygen required to oxidize chemically the organic waste present in the effluent. The temperature of the recirculating electrolyte also noted down for each $1 \mathrm{hr}$. The effluent treatment was done using batch reactor with electrolytic recirculation. In the present study, the experiments were carried out for various current densities, the flow rates and concentration of supporting electrolytes for the various reservoir volumes.

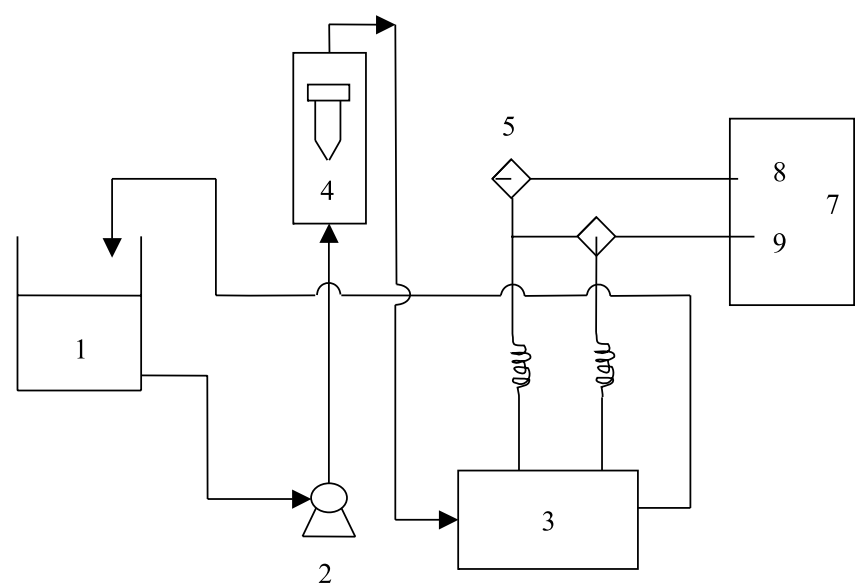

1. Reservoir, 2. Pump, 3. Electrochemical reactor, 4. Flow meter, 5. Ammeter, 6. Voltmeter, 7. Power supply, 8. Anode, 9. Cathode

Figure 1. The schematic of the experimental setup

The various experimental parameters measured are listed in the Table 1. COD of the treated samples was measured by open reflux method ${ }^{14,15}$.
Table 1. Experimental parameters measured and computed during electrolysis

\begin{tabular}{|l|l|}
\hline S. No. & Parameters \\
\hline 1. & Current, $\mathrm{A}$ \\
\hline 2. & Cell voltage, $\mathrm{V}$ \\
\hline 3. & COD in the reservoir, $\mathrm{ppm}$ \\
\hline 4. & Percentage reduction of COD, $\%$ \\
\hline 5. & Energy consumption, $\mathrm{kW} \mathrm{h}(\mathrm{kg} \mathrm{COD})^{-1}$ \\
\hline 6. & Temperature, ${ }^{\circ} \mathrm{C}$ \\
\hline 7. & Average flux, $\mathrm{kg} \mathrm{COD} \mathrm{hr}^{-1} \mathrm{~m}^{-2}$ \\
\hline
\end{tabular}

\section{RESULTS AND DISCUSSIONS}

\section{Influence of sodium chloride $(\mathrm{NaCl})$ concentration on $\mathrm{COD}$ removal}

Tests were run at different sodium chloride concentrations and the other parameters like current density $(2.5 \mathrm{~A}$ $\mathrm{dm}^{-2}$ ), the flow rate $20 \mathrm{LPH}$, the reservoir volume (1 litre) were kept constant. The increasing concentration of supporting electrolyte (sodium chloride) increases the rate of reduction of COD of the effluent ${ }^{16}$, as shown in Table 2 . From the experimental results, the optimum conditions for electrooxidation of effluent were chosen as $4 \mathrm{~g} \mathrm{l}^{-1}$. Increasing sodium chloride concentration increase the concentration of chlorine through the increase of current efficiency of chlorine formation at the anode and it also suppresses chlorine hydrolysis, thus increasing the concentration of unhydrolysis chlorine in the solution which reacts with lignin, producing water soluble electrolignins and easily oxidizable chlorolignins ${ }^{17-19}$. The catalytic action of sodium chloride has been attributed to the participation of electro generated hypochlorite in the oxidation of organics near to the anode or/and in the bulk of the electrolyte ${ }^{20}$. This reaction mechanism was well explained in literature ${ }^{2,11,20}$. Increasing the sodium chloride concentration not only decreases the average cell voltage between the anode and the cathode, but also the energy consumption per $\mathrm{kg}$ of COD removal of the effluent decreases. The same trend was observed by Ugurlu et al $2006^{9}$. The increase in the concentration does not affect the average flux which was more or less constant $\left(0.00408 \mathrm{~kg} \mathrm{COD} \mathrm{hr}^{-1} \mathrm{~m}^{-2}\right)$. The average flux is defined as the total amount of $\mathrm{COD}$ reduced per unit time per unit area.

Table 2. Influence of supporting electrolyte on COD removal

\begin{tabular}{|l|c|c|c|c|c|}
\hline S.No. & $\begin{array}{c}\text { Oxidant } \\
\text { amount/g I }\end{array}$ & \multicolumn{2}{|c|}{ COD/ ppm } & $\begin{array}{c}\text { \% reduction } \\
\text { of COD }\end{array}$ & $\begin{array}{c}\text { Energy } \\
\text { consumed } \\
(\mathrm{kwh} / \mathrm{kgCOD})\end{array}$ \\
\hline & & Initial & Final & & \\
\hline 1. & Nil & 3840 & 2560 & 33.33 & 40.12 \\
\hline 2. & 1.0 & 3840 & 2400 & 37.50 & 35.10 \\
\hline 3. & 2.0 & 3840 & 2310 & 39.84 & 26.65 \\
\hline 4. & 3.0 & 3840 & 1920 & 50.00 & 21.71 \\
\hline 5. & 4.0 & 3840 & 1792 & 53.33 & 15.23 \\
\hline 6. & 5.0 & 3840 & 1695 & 55.85 & 17.21 \\
\hline
\end{tabular}

\section{Influence of current density on COD removal}

The current density was changed within the limits of $1 \mathrm{~A}$ $\mathrm{dm}^{-2}$ to $5 \mathrm{~A} \mathrm{dm}^{-2}$. During the study of the influence of current density on the COD removal, the other parameters like effluent flow rate (20LPH), reservoir volume (1.5 litres), the amount of supporting electrolyte $\left(4 \mathrm{~g} \mathrm{l}^{-1}\right)$ were 
kept constant. From the observed experimental data, it is evident that the COD reduction depends on the current density ${ }^{\mathbf{1 1 , 2 0}}$. In addition, it is observed that the increase in the current density increases the removal of COD up to $52.86 \%$ as shown in Table 3. But during the process the average cell voltage was increased and also the energy consumed per $\mathrm{kg}$ of COD removal increased in result. The increase in current density did not affect the temperature of the electrolyte $\left(32^{\circ} \mathrm{C}-35^{\circ} \mathrm{C}\right)$. Next the reservoir volume was increased from 1 litre to 1.5 litres and 2 litres the other conditions were same as to the 1 litre. From these results, it was observed that if the reservoir volume was increased, then the slight decrease in the \% of the COD reduction is observed.

Table 3. Influence of Current Density on COD removal

\begin{tabular}{|l|c|c|c|c|c|}
\hline S.No. & $\begin{array}{c}\text { Current } \\
\text { density/ } \\
\mathrm{A} \mathrm{dm}^{-2}\end{array}$ & \multicolumn{2}{|c|}{ COD/ppm } & $\begin{array}{c}\text { \% reduction } \\
\text { of COD }\end{array}$ & $\begin{array}{c}\text { Energy } \\
\text { consumed } \\
(\mathrm{kw} \mathrm{hr} / \mathrm{kg} \\
\text { COD })\end{array}$ \\
\hline & & Initial & Final & & \\
\hline 1. & 1.0 & 3840 & 2630 & 31.51 & 9.78 \\
\hline 2. & 2.0 & 3840 & 2515 & 34.51 & 25.61 \\
\hline 3. & 3.0 & 3840 & 2350 & 38.80 & 41.23 \\
\hline 4. & 4.0 & 3840 & 1955 & 49.09 & 45.15 \\
\hline 5. & 5.0 & 3840 & 1810 & 52.86 & 54.38 \\
\hline
\end{tabular}

\section{Influence of flow rate on COD removal}

The flow rates of the recirculating electrolyte were changed from 20 to $100 \mathrm{LPH}$ in different ranges. The other conditions kept constant were current density $2.5 \mathrm{~A} \mathrm{dm}^{-2}$, reservoir volume (1lit), supporting electrolyte $\left(4 \mathrm{~g} \mathrm{l}^{-1}\right)$. The influence of the flow rate on the COD removal is shown in table 4 . From this table 4 it is cleared that if the flow rate of the recirculating electrolyte is increased, there is decrease in the percentage of the COD reduction. At the flow rate at $20 \mathrm{LPH}$ for 1 litre reservoir volume, the $\%$ of COD reduction is 53.38 and if the flow rate is increased to 100 $\mathrm{LPH}$, then the \% of COD reduction is $49.48 \%$. Due to the increase in the flow rate, the cell voltage between the electrodes and the power consumption are slightly increased. The same results were observed in the literature ${ }^{\mathbf{1 9}}$.

Table 4. Influence of Flow rates on the COD removal

\begin{tabular}{|l|c|c|c|c|c|}
\hline S.No. & $\begin{array}{c}\text { Flow } \\
\text { rate/ } \\
\text { LPH }\end{array}$ & \multicolumn{2}{|c|}{ COD/ ppm } & $\begin{array}{c}\text { \% reduction } \\
\text { of COD }\end{array}$ & $\begin{array}{c}\text { Energy } \\
\text { consumed } \\
\text { (kwh/kg COD) }\end{array}$ \\
\hline & & Initial & Final & & \\
\hline 1. & 20 & 3840 & 1790 & 53.38 & 19.23 \\
\hline 2. & 40 & 3840 & 1830 & 52.34 & 18.90 \\
\hline 3. & 60 & 3840 & 1880 & 51.04 & 20.24 \\
\hline 4. & 80 & 3840 & 1910 & 50.26 & 20.19 \\
\hline 5. & 100 & 3840 & 1940 & 49.48 & 20.49 \\
\hline
\end{tabular}

\section{Residence time distribution studies in an electrochemical} reactor

In the experimental study of RTD flow a tracer tags elements and the variation of tracer concentration in the exit stream with respect to time was measured. The injection of the tracer into the flow stream is frequently done in such a manner that it can be well approximated by a delta function. The tracer concentration distribution in the exit has a characteristic shape depending upon the dispersion and on the location of tracer injection and detection. In the electrochemical reactor the tracer (concentrated Hydrochloric acid) was injected at the inlet and then the set of tracer concentration versus time data at the outlet for different flow rates were obtained and tabulated. The dispersion model has been applied for the concentration-time data for different flow rates to describe the non-ideality and the conversion of organic matters in the electrochemical reactor and from these results the type flow such as plug flow or mixed flow and type of the reactor-like plug flow reactor or mixed flow reactor has been found ${ }^{\mathbf{1 3}}$.

\section{Influence of flow rates on the tracer outlet concentration}

An idealized pulse tracer input is modified if dispersion exists in the reactor. Variance indicates the spread of residence time distribution. A higher value of variance means that the time distribution spread is large. For a small value of dispersion number the spread of the tracer curve does not change much in the shape during the time pride of measurement. It can be seen that under such conditions the dispersion model predicts a symmetrical distribution of the tracer at any instant. The general factors which can effect dispersion are geometry of the unit, scale of mixing phenomena, position as of the inlet and outlet, the power input per unit volume, the input feed velocity and its fluctuations and density \& temperature difference between the input flow rate and the reactor contents. From the experimental results (from the table 5) it is observed that when the flow rate is increased then the variance $\left(\sigma^{2}\right)$ and dispersion number is also gets increased ${ }^{\mathbf{1 3}}$.

Table 5. Variance and dispersion number for different flow rates

\begin{tabular}{|l|c|c|c|}
\hline S.No. & Flow rate (LPH) & $\begin{array}{c}\text { Variance } \\
\left(\sigma^{2}\right)\end{array}$ & Dispersion Number \\
\hline 1. & 5 & 0.165 & 0.079 \\
\hline 2. & 10 & 0.283 & 0.100 \\
\hline 3. & 15 & 0.354 & 0.132 \\
\hline 4. & 20 & 0.529 & 0.161 \\
\hline 5. & 25 & 0.789 & 0.234 \\
\hline
\end{tabular}

\section{Electrochemical Reactor Modeling}

The Pseudo steady state theory which is based on the concept of no accumulation of the intermediate in the reactor helps to obtain the rate of the reaction in the batch reactor with electrolytic recirculation. Under steady state conditions it can be assumed that the reactor is ideal $\mathrm{CSTER}^{\mathbf{1 1}}$ and the performance equation can be written as $\tau_{R}=\frac{V_{R}}{Q}=\frac{C-C^{\prime}}{-r}$

Where,

-r - The rate of disappearance of organic pollutants

The rate of disappearance of organic pollutants is directly proportional to concentration of organic pollutants ' $\mathrm{C}$ ' and the pseudo first order kinetic equation is given by $-r=K a C$

Where,

-r - rate of disappearance of organic pollutants in the reactor.

$\mathrm{K}$ - Electrochemical reaction rate constant, $\mathrm{cm} \mathrm{sec}^{-1}$. VR - Active volume of reactor, litre.

$\mathrm{Q}$ - Volumetric flow rate of electrolyte, LPH. 
$\tau_{R}$ - spare time for the reactor $\left(V_{R} / Q\right)$, hour.

$\mathrm{C}^{\prime}$ - concentration of organic pollutants in leaving the stream of the reactor, ppm.

$\mathrm{C}$ - concentration of organic pollutants in entering the stream of the reactor, ppm.

a - Specific electrode area $\left(A / V_{R}\right), \mathrm{dm}^{2}$.

Equations (1) and (2) can be written as

$\frac{C^{\prime}}{C}=\frac{1}{1+K A / Q}$

For batch reactor with the electrolytic recirculation reactor system, the mass balance can be written as,

$V \frac{d C}{d t}=Q\left(C-C^{\prime}\right)$

From the above equations, we get

$\ln C / C o=-K A / Q(1+K A / Q) t / \tau$

By plotting the above equation (5), which gives a straight line and the slope value (rate constant K). Here, Co is the initial concentration of organic pollutants in the reservoir, $\mathrm{C}$ is the concentration of organic pollutants at time ' $\mathrm{t}$ ' in the reservoir, $\mathrm{Q}$ is volumetric flow rate, $\mathrm{V}$ is the volume of the reservoir and $\tau$ is space time for the reservoir.

\section{Influence of various parameters on electrochemical reac- tion rate constant}

By using the experimental results, the rate constant values were determined for different supporting electrolyte concentration, different current densities, different flow rates and for different reservoir volumes. Table 6 shows that the variation of electrochemical reaction rate constant with respect to various current density and electrolyte reservoir volume for the flow rate of $20 \mathrm{LPH}$. From the experimental results, it is observed that if the amount of supporting electrolyte increases then the rate constants is also increased. The rate constant was decreased with an increase in the reservoir volumes when all the other parameters were constant. From the experimental results it was also observed that if the flow rate of recirculating electrolyte increases, then the rate constants are decreased because of the contact time between the electrode and the circulating electrolyte in the reactor is decreased ${ }^{\mathbf{1 1}}$.

Table 6. Influence of various parameters on the rate constant

\begin{tabular}{|l|c|l|l|l|}
\hline \multirow{2}{*}{ S. No. } & \multirow{2}{*}{ Current density $/ \mathrm{A} \mathrm{dm}^{-2}$} & \multicolumn{3}{|c|}{ Rate constant, $\mathrm{kx} 10^{3} / \mathrm{cm} \mathrm{s}^{-1}$} \\
\cline { 3 - 5 } & & 1 litre & 1.5 litres & 2 litres \\
\hline 1. & 1 & 0.5763 & 0.5535 & 0.5342 \\
\hline 2. & 2 & 0.5835 & 0.5721 & 0.5658 \\
\hline 3. & 3 & 0.6228 & 0.6057 & 0.5898 \\
\hline 4. & 4 & 0.6389 & 0.6185 & 0.5981 \\
\hline 5. & 5 & 0.6549 & 0.6301 & 0.6109 \\
\hline
\end{tabular}

\section{CONCLUSION}

The present study has been carried out with a view to investigating the electrochemical oxidation of organic compounds present in the pulp \& paper mill effluent. From the experimental results it is observed that the increasing concentration of supporting electrolyte (sodium chloride) increases the rate of reduction of COD of the effluent, increase in the current density increases the removal of COD. If the flow rate of the recirculating electrolyte is increased, then the decrease in the percentage of COD reduction was observed. When the flow rate is increased then the variance $\left(\sigma^{2}\right)$ and dispersion number is also increased. Residence time Distributions (RTD) studies have been conducted to study the behavior of the electro chemical reactor and for which, the impulse was injected suddenly. Finally, it was concluded that the computation of the dispersion coefficient is closely linked to RTD in an electrochemical reactor.

\section{NOMENCLATURE}

a - Specific electrode area, $\mathrm{dm}^{2}$.

A - Active electrode area, $\mathrm{dm}^{2}$.

Co - Initial concentration of organic pollutants in the effluent, ppm.

C - Concentration of organic pollutants in the reactor outlet stream, ppm

C - Concentration of organic pollutants in the reactor inlet stream, ppm

$\mathrm{K}, \quad-$ Electrochemical reaction rate constant, $\mathrm{cm} \mathrm{sec}^{-1}$

Q - Volumetric flow rate of effluent to reservoir, LPH.

-r $\quad$ - The rate of disappearance of organic pollutants

$\mathrm{t}$ - Contact time, second and hours

$\sigma^{2} \quad$ - Variance

$\mathrm{V}$ - Volume of reservoir, litre.

VR - Volume of reactor, litre.

$\tau, \tau_{\mathrm{R}}-$ Space time of the effluent in reservoir and reactor respectively, hour.

\section{ABBREVIATIONS}

COD - Chemical Oxygen Demand, ppm

C.D. - Current Density, A dm ${ }^{-2}$

CSTER - Continuous stirred tank electrochemical reactor.

ppm - parts per million.

\section{LITERATURE CITED}

1. Fontanier, V., Farines, V., Albet, J., Baig, S. \& Molinier, J. (2006). Study of catalyzed ozonation for advanced treatment of pulp and paper mill effluents. Water Res., 40, 303-310. DOI:10.1016/J.WATRES.2005.11.007.

2. Wang, B., Kong, W. \& Ma, H. (2007). Electrochemical treatment of paper mill wastewater using three-dimensional electrodes with $\mathrm{Ti} / \mathrm{Co} / \mathrm{SnO}_{2}-\mathrm{Sb}_{2} \mathrm{O}_{5}$ anode, J. Hazard. Mater, 146, 295-301, DOI:10.1016 /J.JHAZMAT. 2006.12.031.

3. Amat, A.M., Arques, A., Lopez, F. \& Miranda, M.A. (2005). Solar photo-catalysis to remove paper mill wastewater pollutants. Solar Energy, 79, 393-401. DOI:10.1016/ J.SOLENER.2005.02.021.

4. Kim, S., Geissen, S. \& Vogelpohl, A. (1997). Landfill leachate treatment by a photoassisted fenton reaction, Water Sci. Technol. 35, 239. DOI:10.1016/J.WATRES.2003.08.007.

5. Wong, S.S., Teng, T.T., Ahmada, A.L., Zuhairi, A. \& Najafpour, G. (2006). Treatment of pulp and paper mill wastewater by poly acrylamide (PAM) in polymer induced flocculation, J. Hazard. Mater., 135, 378-388. DOI:10.1016/ j.jhazmat.2005.11.076.

6. Chiang, L., Chang, J. \& Wen, T. (1995). Indirect oxidation effect in electrochemical oxidation treatment of landfill leachate, Water Res. 29, 671. DOI:10.1016/0043-1354(94)00146-X.

7. Shen, Z.M., Yang, Hu, X.F., Lei, Y.M., Ji, X.L., Jia, J.P., \& Wang, W.H. (2005), Dual electrodes oxidation of dye wastewater with gas diffusion cathode, Environ. Sci. Technol. 39, 1819-1826. DOI: 10.1021/es901269s.

8. Panizza, M., Bocca, C. \& Cerisola, G. (2005). Electrochemical treatment of wastewater containing 
polyaromatic organic pollutants, Water Res. 34, 2601-2605. DOI: 10.1021/es049730n.

9. Fahidy, T.Z. (1985). Principles of Electrocheical reactor analysis, Elsevier, Amsterdam, 136-140. www.fkit.hr/files/ dodiplomski/stari/C.

10. Walsh, F.C. (2001), Electrochemical technology for environmental treatment and clean energy conversion, Pure Appl. Chem., 73, 12, 1819-1837. DOI:10.1351/pac200173121819.

11. Ugurlu, M., Karaoglu, M.H. \& Kula ,I. (2006). Experimental investigation of chemical oxygen demand, lignin and phenol removal from paper mill effluents using three-phase three-dimensional electrode reactor, Polish J. of Environ. Stud., 15, 647-654.

12. Mustoe, L.H. \& Wragg, A.A. (1981), Effects of flow and electrical arrangement on the performance of some simple electrochemical reactor systems, J. Chem. Technol. Biotechnol., 31, 317-326, DOI: 10.1002/jctb.503310143.

13. Levenspiel, O. (1999). Chemical Reaction Engineering, John Wiley \& Sons, New York. http://khup.com/keyword/chemical-reaction-engineering-levenspiel.html.

14. Dara, S.S, (1991).A Text Book of experiments and calculations - Engineering chemistry; Chand .S.and company Ltd., New Delhi. http://khup.com/keyword/engineering-chemistry-s-chand-publications.html.

15. APHA (1995), Standard Methods for the Examination of Water and Wastewater. http://top-pdf.com/apha-2120-f.html.

16. Dümmling, S., Eichhorn, E., Schneider, S., Speiser, B., Würde, M. (1996). Recycling of the Supporting Electrolyte Tetra(n-butyl)ammonium Hexafluorophosphate from Used Electrolyte Solutions, Current Separations, 15, 53-56. http:// www.currentseparations.com/issues/15-2/cs15-2b.pdf.

17. Nassar, M.M., Fadaly, O.A. \& Sedahmed, G.H. (1983), A new electrochemical technique for bleaching cellulose pulp, J. Appl. Electrochem., 13, 663-667, DOI: 10.1007/BF00617824. 18. Alverez-Gall Bergos, A. \& Pl Etch Er, D. (1999), The removal of low level organics via hydrogen peroxide formed in a veticulated vitreous carbon cathode cell. Part: The removal of phenols and related compounds from aqueous effluents, Electrochim. Acta, 44, 2483. DOI:10.1016/S00431354(01)00147-6.

19. Chen, X., Ch En, G.H. \& Yu E, P.L. (2000), Separation of pollutants from restaurant wastewater by electrocoagulation, Sep. Purif. Technol., 19, 65. Doi:10.1016/S13835866(99)00072-6.

20. Raghu, S. \& Ahmed Basha, C. (2007), Electrochemical treatment of Procion Black 5B using cylindrical flow reactor - A pilot plant study, J. Hazard. Mater. B139, 381-390, DOI:10.1016/j.jhazmat. 2006.06.082. 